\title{
Africa
}

http://journals.cambridge.org/AFR

Additional services for Africa:

Email alerts: Click here

Subscriptions: Click here

Commercial reprints: Click here

Terms of use : $\underline{\text { Click here }}$

\section{BANKING IN THE BUSH: WAITING FOR CREDIT IN SOUTH AFRICA'S RURAL ECONOMY}

\section{Elizabeth Hull}

Africa / Volume 82 / Special Issue 01 / February 2012, pp 168 - 186

DOI: 10.1017/S0001972011000702, Published online: 19 January 2012

Link to this article: http://journals.cambridge.org/abstract_S0001972011000702

How to cite this article:

Elizabeth Hull (2012). BANKING IN THE BUSH: WAITING FOR CREDIT IN SOUTH AFRICA'S RURAL ECONOMY. Africa, 82, pp 168-186 doi:10.1017/

S0001972011000702

Request Permissions : $\underline{\text { Click here }}$ 


\title{
BANKING IN THE BUSH: WAITING FOR CREDIT IN SOUTH AFRICA'S RURAL ECONOMY
}

\author{
Elizabeth Hull
}

The South African countryside has, for many years, been the object of 'developmental' intervention by the government, parastatals and, to a lesser extent, private industry. A significant part of this has involved attempts to bolster local economies with large injections of cash in the form of loans provided to small-scale farmers and other rural businesses (Witt et al. 2006; James 2007). These have come mainly from state-supported institutions such as the Land Bank, given the lack of willingness on the part of the commercial banking sector to lend, until recently, to 'high-risk' groups (Porteous and Hazelhurst 2004: 78-81). The failure of such efforts, due largely to poor levels of debt repayment, ${ }^{1}$ signals an array of underlying institutional, economic and infrastructural deficiencies, often rooted in deeper histories of rural degradation and turmoil resulting from successive colonial and apartheid policies (Bryceson 2004). The shift over the last few years to microfinance represents the most recent effort to provide credit to the informal self-employed, and is part of a process of banking reform in which the so-called 'second economy' is targeted comprehensively with the aim of bringing it under the regulatory mechanisms of the formal sector. Pedagogy and financial self-discipline play an important part in this, with eligibility for loans being dependent on savings. It remains to be seen, however, to what extent the optimism of this recent shift to microfinance is deserved, especially in a context characterized by entrenched histories of loan defaulting and saturated local economies with poor access to markets (see Servet 2010; Bateman 2010). As Parker Shipton reminds us, while credit 'promotes itself easily', it also implies indebtedness, and all the complicated repercussions this may bring (2010: 4-6).

Current microfinance institutions are distinguished from previous loan programmes because they represent the post-apartheid government's emphasis on decentralization and citizen participation in development. The costly tasks of bureaucratic administration and management are devolved to locally founded organizations, and buttressed by an ideology of self-help, individual social responsibility and entrepreneurialism. The real participatory potential of local development initiatives, however, often remains limited in practice (Marais 2011: 352-6; Sithole et al. 2007). Development generally takes place within circumscribed parameters with little genuine input from its recipients who, on the contrary, tend to find themselves in perpetual limbo, waiting for wellintentioned initiatives to begin functioning. In the space of this disconnect

\footnotetext{
ElizABeth Hull is a Leverhulme Centre for Integrative Research in Agriculture and Health Postdoctoral Fellow in the Food Studies Centre, School of African and Oriental Studies. The research for this article was undertaken during a postdoctoral fellowship in Anthropology at the London School of Economics. Email: e.hull@soas.ac.uk

${ }^{1}$ A notorious example was Provident SA, which shut down in 2001 (Porteous and Hazelhurst 2004: 84).
} 
between planners and beneficiaries, and in the temporal suspension caused by delay, unexpected or unintended processes emerge during which benefits may accrue. As Deborah James writes, for instance, in relation to processes of land reform, 'It is when the fulfilment of promises is indefinitely delayed that people may, instead, choose the option of full-blown political patronage' (James 2007: 223).

In this article, I describe how residents of an agricultural region in the province of KwaZulu-Natal both wait and search for credit, and the types of activities which emerge in the interim. Encounters with government and other institutions, as anthropologists have frequently shown, are not smooth and constant, but intermittent and partial, planned or unplanned, punctuated by particular events, and intermingled with a range of strategies also involving kin, friends and other local people (see, for example, Shipton 2010; James 2007; Gupta 1995). I give an example of how this takes place in Makhathini, KwaZulu-Natal, through the story of one aspiring farmer. His account offers an interesting vantage point from which to view the setting up of a microfinance bank, a recent initiative of which he is a member. ${ }^{2}$ A government stipulation was that the bank demonstrate its effective operation through regular inflows and outflows of cash, prior to paying out any loans. Accordingly, members were encouraged to invest money in order to qualify for a loan at a later stage. The research was based on the initial stages of formation of the microfinance institution, when members were saving in the bank but before any loans were distributed. Thus, the purpose of the article is not to analyse the institution per se, nor to assess its success or failure, but rather to describe how new expectations for credit featured within a range of diverse financial strategies. It gives an account of the factors that enhanced or inhibited the willingness of members to invest in the bank, and the processes that occurred while members were 'waiting for credit'.

\section{LOCATING MAKHATHINI}

Makhathini is an area of around 13,000 hectares spread over the low-lying areas east of the southern Lebombo mountain range in northern KwaZulu-Natal. It is the site of a major development, the Makhathini Irrigation Scheme, which occupies an area of 3,864 hectares, most of which is divided into ten-hectare plots rented and managed by 314 individual farmers. Many of these engage in smallscale commercial farming. The remaining land within the scheme is divided into 243 smaller 'gardens' of 0.2 hectares each. Beyond the scheme live 'dry-land farmers' and other residents, who rely on small and intermittent rainfall and various other limited sources of income. Mixed cropping is the norm, with maize, sugarcane, beans and a variety of vegetables grown widely. Following the closure of the local cotton ginnery in 2008, cotton is barely grown in the area, although it had been the main cash crop for years.

As is widely recognized in the literature on small-scale farming in South Africa, the majority of individuals that describe themselves as farmers do not, in fact, rely

\footnotetext{
${ }^{2}$ The name of the microfinance bank is not disclosed in this article. All names of individuals are pseudonyms.
} 
exclusively on farming. ${ }^{3}$ On the contrary, despite the visual landscape which suggests a local economy driven by agriculture, subsistence for the majority of its residents rests predominantly upon the receipt of government grants, including pensions, child grants and disability grants. In addition, petty trade and piecemeal jobs of various sorts, and remittances from family members working in the city, all contribute to incomes. A small proportion of Makhathini's residents work in the formal sector, usually in public sector jobs as nurses, teachers, police or municipal government administrators. According to the deprivation index of the Health District Barometer of 2008/9, based on a range of demographic and socioeconomic data, the district of Umkhanyakude - under which Makhathini falls - is the second most 'deprived' of 52 provinces nationally (Day et al. 2009: 197).

Government intervention in agriculture in the region, beginning under colonialism, intensified following the construction of the large Jozini Dam in the 1960s, which today supplies the Makhathini Irrigation Scheme. It was originally built to support the relocation of poor white South Africans who were to build farms there, but this relocation never materialized, amid increasing urban employment opportunities during the economic boom of that decade. Over the course of several years, the dam became the focus of new plans to support and develop the surrounding black population (Witt et al. 2006). Thus the abortion of initial plans to improve the lot of poor whites gave rise to a political opportunity of a different sort for the apartheid government as it sought to gain legitimacy for the 'homelands' by measures that included facilitating development in these regions. ${ }^{4}$ Yet this process, as with other homeland policies, was deeply contradictory and divisive. Following the opening of the dam in 1974, 5,000 people were removed and resettled in order to establish the Makhathini Irrigation Scheme, initiating a turbulent and ongoing relationship of distrust between farmers and government that was reinforced by a series of incoherent and inconsistent institutional and political frameworks through which development was attempted (ibid.: 500).

Despite the government's efforts, particularly via the irrigation scheme, to create a cadre of middle-class farming entrepreneurs, farmers proved persistently dependent on external credit (cf. Francis 2000). Loans provided to farmers by the KwaZulu homeland government were not repaid, leading to an entrenched culture of loan defaulting by the end of the decade. During the 1990s, a new loan scheme was set up by the Land Bank, a government-supported development bank. But this came to an end in 2004, by which time the sum of defaulted loans had reached R22.7 million (about $£ 2$ million). Makhathini received international attention, emerging at the centre of a controversial and polarized debate over the impact of the genetically modified Bt Cotton, introduced in the area in 1998. While some initial research proclaimed the crop a success (Thirtle et al. 2003), others declared its uptake a sign of necessity rather than choice, given the

\footnotetext{
${ }^{3}$ Smallholder farmers in South Africa are rarely able to earn their income from farming alone (James 2007).

${ }^{4}$ The 'homelands', or bantustans, were territories set aside by the apartheid government for the purpose of creating ethnically homogeneous, independent states for South Africa's black ethnic groups. Ten were created altogether, including KwaZulu ('place of the Zulus'), within which the area of this study formerly was situated. With the inception of liberal democracy in 1994, the bantustans were dismantled and new borders were created for nine national provinces.
} 
circular dependency upon cotton seed and credit that by now had emerged (Pschorn-Strauss 2005; Mayet 2007; Witt et al. 2006). Its introduction was described as

the latest in a long series of technocratic interventions that have consistently failed to transform Makhathini into a hotbed of commodity production, but have instead been guided by a technocratic will to make cotton a lucrative cash crop, regardless of local conditions, needs or ecology. (Witt et al. 2006: 501)

During the period of research in 2010, the area was steeped in political dispute and uncertainty, with a messy and incomplete transfer of land from government to chiefly control as part of the national land reform process; this generated seemingly irresolvable disputes between the two chiefs operating in the area, and considerable uncertainty among farmers about the status of their land-leasing arrangements. In addition, several promised government interventions were still awaiting evidence of implementation including, among others, a new cotton mill, a marketplace where farmers could sell their products to long-distance traders with the guarantee of price control, and a microfinance bank which had been set up and was accepting investments but had not yet begun administering loans.

In the meantime, immediate cash flows circulated through a multitude of locally based informal financial organizations, including stokvels, savings clubs and a variety of other rotating credit societies. Many of these were based on the idea of saving and credit cycles, though these were generally oriented toward consumptive practices such as funerary or wedding expenses, or lending for the purposes of generating interest, rather than for productive enterprise (cf. Bähre 2007; Shipton 2010). This accords with Porteous and Hazelhurst's observation that microcredit loans given to salaried workers during the 1990s were used primarily for consumption purposes rather than to fund micro-enterprise, in contrast to well-known international models of microfinance such as Grameen. In the Eastern Cape, Bank and Qambata (1999) show that the pensions increase did not lead to investments in agricultural activities and other productive investments, as the government had hoped, but rather was spent on immediate family welfare. Despite this evidence, the microfinance movement expects that credit will be used productively rather than for consumption. The following story describes one person's search for credit, an ongoing process in which the microfinance bank mentioned above featured as one of several institutional encounters.

\section{SNUK'S WORK: MORAL AND SOCIAL HIERARCHIES OF MONEY MAKING}

I first found out about the microfinance bank through Sipho, a resident of the village where I was staying, some forty minutes' drive from Makhathini. I met him in January 2010 at the market held once a month on pension day. I explained that I was doing research about local financial practices: different ways that people generated, saved, exchanged and invested money. He told me that he was a member of a local financial organization, 'a bank run by the people', which was about to be registered as 'an official bank'. I asked him what he meant and he told 
me excitedly, 'It will be a bank, a formal bank like ABSA and all those others. ${ }^{5}$ It will be exactly the same.'

Sipho was not clear on the details, such as who was providing the bank's accreditation or from where the money would come that would be issued as loans. That it was not, in fact, registered with the Reserve Bank and did not fall under the same regulatory mechanisms as ABSA, was neither known by Sipho nor relevant to him. For Sipho, what made the bank 'formal' - and thus akin to other high street banks - was the services it would offer and, more especially, the accreditation it was about to receive. What Anna Tsing (2000) has described as the 'economy of appearances' is crucial here, whereby material certificates, documents and the aesthetics of the bank itself are essential to its identity as a formal institution, a point to which I return.

Sipho's understanding of what counted as 'formal' was shaped by some existing experience with the banking sector. He was a 26-year-old aspiring farmer who, despite having no regular income and currently living off his mother's pension, was determined to establish a farming business. He was ambitious and hoped to pursue various businesses after starting a farm.

Sipho completed his matriculation (university entrance certificate) in 2005 with excellent results and fluency in English. He moved to the town of Port Shepstone, south of Durban, where his sister's partner secured him a job working for a delivery company. He found the work boring, and came home after six months when his brother informed him that a temporary teaching post in English and History had become available at his former school. He applied and got the position. He worked there for a year and a half until his contract expired at the end of 2007. At this point he decided that the time had come to pursue his childhood ambition of farming. He got a job in a nearby bottle store while accumulating information about how to start a business, meeting with various government advisers and visiting banks in search of a loan. During the first year he learned fast, soon discovering that it was more complex than he had realized to secure credit. He playfully mocked his own earlier naïvety:

At the start I didn't know a single thing! I thought I would go to a bank myself and then tell them with my own utterances. I said to myself, 'I have to tell them confidently, so that maybe they will give me that capital that I want.' I planned that I would say, 'I'm having this career that I am glowing about! So I am requesting R500,000 from you.' I thought that they would respond by saying, 'Oh, are you sure about that career?' I would respond by saying, 'More than sure!' And I thought that that would be the only thing they would be looking for from me. After that, I thought that they would ask for my account number, then I will give it to them. Then I will get the money! I said to myself, 'It will be as easy as that,' while I didn't know!

It took several months before Sipho had a clear sense of what was required. In 2009 , after contacting many companies and agencies in search of advice, and with the help of a friend from his church congregation who owned a beer distribution company, he eventually started to write a business plan. He was informed by a

\footnotetext{
${ }^{5} \mathrm{ABSA}$ is a large commercial high-street bank with branches in both nearby towns.
} 
person at Ithala bank (a South African high-street bank) that in order to access a loan, he must submit his completed business proposal and a copy of the lease for the land he planned to use. In addition, a government adviser in nearby Jozini suggested he form a cooperative, because 'sole traders' found it more difficult than cooperatives to access loans. He also needed to apply for a CK form which would signify that the business was officially recognized and incorporated. ${ }^{6}$ Forming the cooperative with three other people that he knew, he applied for the CK, which he finally received on 26 March 2010, and with which he was able to open a business account. He also started negotiating, but inconclusively, with various farmers to hire a plot of land. On 8 May, he took his CK to the South African Revenue Service to register for tax payments, a process required in order to validate the CK form. He explained to me the importance of the form: 'This CK is everything.... It's an official document for everyone to start a business with. It means that the business is formal, not informal.'

Sipho also used this form in order to join the government database for tender contracts. Such short-term contracts have become common in South Africa in recent years and have received widespread media attention following several notorious corruption cases. They are well-known and highly sought-after because of their extremely lucrative revenues (see McNeill, this volume). Sipho joined the tender database, preferring to keep open several income options rather than investing all his energies into one. A further incentive was that farming required significant input capital, and that unexpected scenarios often arose in farming that required financial resources. Bidding for tenders was a short-term means designed to serve a longer-term goal.

That Sipho's day-to-day subsistence was assured by his mother's pension made possible such planning in the short and medium terms, a temporal dimension which often influences the nature of informal economic activity in South Africa. Nonetheless, to accomplish even such immediate objectives as entering the tender database, capital was required. Without any source of income, current employment or savings, how, I asked Sipho, had he managed to pay for the CK form, which cost him R750? He laughed, rather embarrassedly, somewhat reluctant to tell me. Later in the conversation, he said 'No, I can tell you. I was selling wood. I used to collect the wood into big bundles and sell it for R150 each.' It was hard work, he explained, because he was doing it alone. He had to carry each of the logs up the mountainside to his home from the wooded valley below. People drove to his house to collect it, because the bundles were too large to be carried. He earned a lot of money, he told me, because there was a very high demand for the wood. 'I sweated for this CK!' he repeatedly told me. I asked him why he didn't want to tell me about it at first. He laughed, saying 'Ah, it's snuk's work', making a dismissive gesture with his hand: snuk is a colloquial term for 'low' or 'stupid'. 'The work is just basic,' he added, searching for the right words, 'just labour.'

\footnotetext{
${ }^{6}$ The $\mathrm{CK}$ is an official document issued by the Companies and Intellectual Property Registration Office (CIPRO) of the Department of Trade and Industry, whose slogan - 'gateway to formal economic participation' - exemplifies 'formality' as a popularised term. <http://www. cipro.gov.za >, accessed 10 May 2010.
} 
Sipho's story demonstrates that entering into a process of formalization did not entail relinquishing his engagement in popular economies. Indeed, given the expensive administrative and transport costs of acquiring the CK form, the process of formalization actually generated the activities to which he referred pejoratively as 'snuk's work'. The so-called 'formal' was here giving rise to 'informal' activities. To see them as detached economic spheres would be misleading. Nonetheless, his own reference to 'formal' and 'informal' suggests that he perceived them as separate and, more so, that they formed a hierarchical relationship to one another such that the former was more desirable. His reference to 'snuk's work', as well as his general embarrassment that he made money from collecting and selling wood, indicated that, despite their money-generating potential, he viewed such pursuits as inferior since they lacked the status associated with business ownership. His self-mockery about his earlier inexperience in loan seeking, accentuated by the physical 'labour' associated with informality, implied that he felt he had now entered an esoteric realm, to negotiate which a degree of sophistication and skill was required.

Sipho joined the microfinance bank during 2009, after hearing about it from his cousin. He joined in order to receive a loan, but he knew that this was unlikely for some time: it was just one of several options for him. In any case, he needed a substantial loan, more than it was likely to provide. 'All in all,' he said, 'I am not expecting much from this bank. It is still early.' For this reason, and because he had no money to spare, he was not investing savings into the bank - a requirement to gain a loan at a later stage. For Sipho, then, the microfinance bank was merely one of a number of opportunities. As described by the literature on 'multiple livelihoods' (Francis 2000; Murray 2000), it was central to his strategy that he keep open a variety of possibilities: he was reluctant to commit to pursuing any single activity.

By May 2010, Sipho had managed to get a tender contract to build an RDP house. ${ }^{7}$ Rather than securing this job directly from government contractors, he acquired a 'sub-contract' through an intermediary who had already won a contract to build several houses in the area. They agreed verbally to the terms of the job, and Sipho was told he would be remunerated when the job was completed. Sipho employed two bricklayers, including his own cousin, to help him with the job, with the promise of remunerating them at the end. The contractor delivered materials to the site and they began work. About two weeks later, they discovered that they had made an error with the building's measurements. They had to start it again. Sipho's contractor told him that he must pay for the costs of the error, including the building's demolition. Sipho asked him to deduct the amount from his final salary, but the man refused. Clearly distressed, Sipho told me that if he was unable to pay, he feared the government would take him off the tender database. He quickly borrowed R1,900 (about £160) from a friend to cover the costs.

They began work once again, and were making good progress. But two weeks later he encountered another problem. Having informed the contractor that he had run out of materials, he awaited the delivery of more. They did not arrive and,

${ }^{7}$ From 'Reconstruction and Development Programme': social housing provided by the government. 
by the second day, he was becoming frustrated by the delay. After a week or so of waiting, and being unable to contact his employer who failed to answer his calls, Sipho began to realize that the contractor no longer wanted him to work on the job. With growing frustration, he waited on the site for several more days. Following further attempts to contact his employer and an angry letter to government contractors, he finally gave up, realizing that he would be unable to finish the job, pay his labourers or receive any remuneration. Encouraged by me to seek assistance from the government, he insisted that they would not be interested in what he had to say, nor did they have any responsibilities towards him. He was only a sub-contractor. He preferred to put it behind him and search for a new contract.

Sipho's experience supports an increasingly common narrative about tenders being controlled by corrupt middlemen. But Sipho was the victim not only of the behaviour of an individual, but also of a system of deregulated labour and the withdrawal of state responsibility for a sphere of temporary labourers whose work is consequently insecure, despite needing formal accreditation in the form of a $\mathrm{CK}$ document. This pattern is replicated throughout state services such as health, and through microfinance schemes, in which the government increases regulation through procedures such as audit, while withdrawing responsibility by replacing it with intermediary companies, institutions and individuals (Hull, forthcoming). Sipho's impression of tender contracts as high-status, formal and highly lucrative forms of income creation were belied by his experience of one of them. Though he had adopted the perspective of a sharp distinction between 'formal' and 'informal' in the manner in which he spoke about his aspirations, his experiences reflected a different reality, often made up of piecemeal and disconnected encounters, only partially meeting his expectations of them. As Jane Guyer puts it: 'formality is experienced by the population in its plural and concrete forms ... rather than as an enduring generalizable principle' (2004: 158). Despite his initial enthusiasm about the microfinance bank's official status, for instance, the ongoing delay that Sipho observed, along with its failure to adopt the aesthetic signifiers of 'formality', gradually challenged his trust in it.

\section{COMMUNITY BANKING}

The South African Microfinance Apex Fund (SAMAF) was founded in April 2002. A branch of the Department of Trade and Industry, SAMAF's goal is to 'facilitate the provision of affordable access to finance by micro, small and survivalist business for the purpose of growing their own income and asset base' via a 'network of self-sufficient and sustainable microfinance institutions' ${ }^{8}$ Such institutions, some of which are categorized as Financial Services Cooperatives (FSCs), have exemption from the Banks Act, and are governed therefore under a different set of regulations than are larger commercial banks, even though some of the same services are provided. This exemption allows smaller, 'communitybased' organizations to provide financial services without the need to conform to

\footnotetext{
${ }^{8}<$ www.samaf.org.za $>$, accessed 10 October 2010 .
} 
the more complex system of regulations that governs large institutions. One such FSC is that recently set up in Makhathini.

This community bank was founded by a small group of cotton farmers in 2007. Formally a Financial Services Cooperative, it is referred to by its members as a 'bank'. As of September 2010, the bank had approximately 1,200 members, most of whom engaged in some kind of farming-from subsistence to small-scale commercial production - alongside a range of other income-generating activities. The chairperson explained the members' motivations for setting up the bank after they had made contact with SAMAF:

We realized that when we went to institutions to borrow money, we had problems. They used to ask for assets: 'Do you have an asset? Do you own a house?' So that before they give you money you've got to qualify. So it was so hard for us. That is why we decided to see if we can make ourselves a banking institution.

Beginning initially as a project to assist farmers, it later expanded to include anyone in the Makhathini and Jozini area seeking a loan for the purpose of funding microenterprise. SAMAF advised that they must raise an initial $\mathrm{R} 100,000$ (nearly $£ 10,000$ ) in order to qualify for the status of an intermediary institution' that would be eligible for funds. The group of farmers agreed to raise the money by recruiting new members and charging a R100 joining fee. They advertised the bank on a local radio station and quickly raised the necessary funds, storing these in an account held at ABSA in the nearby town of Jozini. It took over three years finally to reach the point of official accreditation. On 22 February 2010 the bank was registered with SAMAF as a Financial Services Cooperative (FSC). On 4 May 2010, the certificate was formally handed to the chairperson of the newly formed community bank during a general meeting to celebrate the bank's accreditation.

In a meeting held during the month prior to this, members were told that they must start saving in order to qualify for loans at a later stage. This was a condition laid down by SAMAF, as a way to ensure the bank's full operation through sufficient inflow and outflow, and to encourage people to save, though it appeared that this had not been explained to members when they joined. An arrangement whereby an amount of R50 (about £4.50) was to be voluntarily invested each month was voted in by members. Despite this lip service to participatory decision making, the announcement created mixed feelings among members, many of whom were already disheartened by an unexpectedly long waiting period since they first joined the bank. One member responded indignantly, accusing the board of leading him to the false belief that his initial payment of R100 would render him eligible for a loan. Standing up and pointing repeatedly at the SAMAF representative, Mandla made it clear that members' distrust of the bank was exacerbated by the representative's absence at previous meetings, which they had expected him to attend. The coinciding of the SAMAF representative's belated arrival and the announcement of further conditions to be met by members evidently compromised Mandla's trust: both in the people deemed to have control of the bank's funds, and in the capability of the institution itself to fulfil the responsibility he felt it ought to have towards him. The calm response of the man from SAMAF diverted the moral onus away from himself and the bank, and on to the members, in an attempt to redefine the terms of their discussion. 
'You expect a loan from the bank,' he said, 'but what do you think the bank expects from you?' He paused, repeated this question, and continued:

If you invest in the bank monthly, then you will be in a favourable position to receive funding. If you are able to invest monthly, these records will be kept about you as a further indication that you are a person who is able to refund, that you are reliable. So as a result you can expect to receive a loan. As you yourself said, you came here to be funded. But if we give you money without being refunded, who will lose out then? It will be us: the bank! So we will give you funding based on your performance. At the moment there is no money available to be lent. But soon it will be there.... The government is here to help you, but it won't help if there is no progress being witnessed. ${ }^{9}$

In discussion with me later, a board member framed the notion of individual responsibility in terms of 'commitment' to the bank: 'Members must start to save in order for us to see how many are committed to the bank. We won't give money to those who aren't committed.'

These comments hint at the existence of a rhetoric that characterized members on the basis of personal qualities such as 'reliability' and 'commitment'. The social, structural and class differences that distinguished people's access to resources, and that crucially influenced their ability to invest in the bank, were unacknowledged. This individualizing discourse is congruent with the 'entrepreneur' model that guides current approaches to microfinance in South Africa, which is based on a similarly celebratory attitude towards individual talent and ingenuity - seen as the driving force of the 'informal' economy - thus obscuring the differing availability of resources that creates advantages or disadvantages for particular people. A SAMAF newsletter of April 2010 (Vol. 6) celebrates the 'success story' of one beneficiary. With the financial assistance of a SAMAFfunded financial intermediary, Mrs Mushope of Thohoyandou had transformed her struggling efforts to make money from sewing Venda traditional clothes into a thriving business employing four people. Subsequently, she was able to extend her house and to send her children to tertiary education. Mrs Mushope represents the model 'entrepreneur' - what SAMAF literature refers to as the 'enterprising poor' - by earning a living from a single, successful business and investing in the future security of her immediate family. Similar 'success stories' of individual businesses are celebrated on SAMAF's website, with terms such as 'true entrepreneur' and 'an example to the youth of South Africa' accompanying the isolated accounts of individual achievements. ${ }^{10}$

As the example of Sipho shows, however, while a minority of the bank's members did pursue a single business idea, others diverged significantly from this model, both because they made use of multiple sources of income, and because they were involved in an extensive network of social relationships that influenced financial income and spending in a manner obfuscated by the nuclear household model suggested in Mrs Mushope's account. ${ }^{11}$ The meritocratic ideology underpinning individual 'success stories' obscures the wider contexts that may

\footnotetext{
${ }^{9}$ This is an approximate translation from Zulu.

${ }^{10}<$ http://www.samaf.org.za/successstories.html >, accessed 19 September 2010.

${ }^{11}$ That many South Africans draw upon 'multiple livelihoods' is a point made extensively in the literature. See, for example, Francis 2000; Murray 2000.
} 
enable or constrain the options available to individuals, regardless of their personal qualities of perseverance, hard work and so on.

Evoking ideas of individual 'innovation' and 'responsibility', a crucial feature of access to the bank's loans is that they are conditional upon regular individual savings in the bank. However, as suggested above, the bank has been introduced into a socially and economically skewed setting: some are in a better position to be able to invest in the bank than others, and hence more likely to access funds. Of the thirteen members interviewed who had reinvested in the bank, ten were farmers working within the Makhathini Irrigation Scheme. None were dry-land farmers. The advantage experienced by farmers working within the scheme, therefore, emerged in the patterns of investment into the bank, as the following examples indicate.

Mr Nyawo has been renting a ten-hectare plot inside the Makhathini Irrigation Scheme since the early 1990s. When we spoke in August 2010, he was farming only six of these ten hectares because he lacked capital to plant the others. He also needed to replant the sugarcane he was growing because the existing crop was old and of poor quality. The revenue he received from selling his sugarcane to a nearby factory was depleted by ongoing debt repayments. He complained, therefore, that he was unable to be fully productive and to make progress. He had recently invested R50 in the microfinance bank in addition to the initial R100 joining fee, and intended to continue investing each month. Indicating that many had already lost hope because of delay, he explained his own motivations for continuing his membership:

I hope to invest in the bank every month, because I want to see my involvement pay off, to see whether it will provide. I won't leave it half-way as others have done ... because this is our final option for obtaining credit. Many people left, saying it wasn't moving. But I will stick with it, even though it has gone much slower than we expected.

Despite working inside the scheme and having the advantage of irrigated land, therefore, Mr Nyawo was struggling to utilize all of the land that he was renting, and was experiencing financial difficulties due, in part, to existing long-term debts. Nonetheless, the fact that his farming business was well-established and received regular revenue meant that he was able to afford the monthly investment of R50 into the bank. His long-standing career as a farmer and his previous experiences of indebtedness spurred his hope in the bank, which he saw as the 'final option' for gaining much needed credit. This was a subdued hope, a last resort, given his and others' disillusionment with a history of similar (failed) projects and the personal indebtedness by which he already felt crippled.

A contrasting example, although with some overlap of shared experience, was that of Mrs Dlamini, who began farming cotton on dry (non-irrigated) land in Makhathini in 1994. Her cotton farming came to an end in about 2008, when the nearby cotton ginnery that had previously processed much of the cotton in the area closed down. Mrs Dlamini stopped farming because of the additional costs of transporting cotton for processing elsewhere. Although describing herself as a cotton farmer, she was currently earning most of her income from making and selling traditional straw mats called amacansi. Her son, who had a temporary job in Johannesburg, sometimes sent money, and she also borrowed small amounts from mashonisas (local moneylenders) when necessary. Unlike the large majority 
of her neighbours, she had no access, either directly or via a family member, to a government grant or pension, rendering her more vulnerable to the irregularities of other income sources. Until about three years ago, she was receiving R500 per month from the government for home-based care work. After these payments ceased, she continued the work on a voluntary basis. She also volunteered for the microfinance bank as a secretary and minute-taker prior to the employment in July 2010 of a full-time administrator. For several months in 2010, cotton farmers were in negotiation with the government to reopen the cotton ginnery in Makhathini. If this goes ahead, she told me, she will resume farming.

She told me why she was drawn to the microfinance bank, explaining that it was impossible to get a loan from normal banks if you did not have a job, because they asked to see your pay slip: 'Even if I tell them I am selling these amacansi they do not believe me.' She hoped to start investing in the microfinance bank from the money she was making from selling amacansi, but when we spoke in September 2010 , she had no money to spare. Ideally, she hoped to continue all these activities so as to keep her income-generating options as varied as possible.

Mrs Dlamini's account is typical. She does not aspire towards one career, but attempts to minimize risk by engaging in a variety of strategies. This is important, particularly in the absence of a stable and regular income source such as a government grant. For her, as for Sipho, the microfinance bank represents merely one of several possibilities. Thus financial stability is not necessarily about having a single successful business, but rather about reducing risk through diverse pursuits: 'Risk explains people's concern to establish and maintain a rural base, to disperse their households and to diversify their sources of livelihood' (Francis 2000: 52).

The closure of the ginnery both highlighted and exacerbated the unequal access to resources of farmers inside and outside the irrigation scheme. Due to the increased transportation costs of processing cotton elsewhere, cotton production had become more expensive. Despite these increased costs, however, many dryland farmers continued growing cotton because of its resilience to low rainfall in contrast to other crop types. Others were forced out of farming altogether, as in Mrs Dlamini's case. In contrast, farmers working within the scheme unanimously shifted to other types of crop production such as maize and sugarcane. Lack of access to irrigated land, therefore, was a key factor influencing the degree of vulnerability experienced by dry-land farmers and the choices available to them. Mrs Dlamini's account suggests that the success of future loans will depend greatly upon a wider set of institutional arrangements, ecological conditions and political interventions. It seems unlikely that, even with access to credit, Mrs Dlamini could afford to continue farming cotton in the absence of a local ginnery. For her, expectations about the microfinance bank were intertwined with a wider set of institutional arrangements and the interactions of these with her own livelihood strategies.

These two accounts challenge the 'entrepreneur' concept and its applicability to popular economies. In certain respects, Mrs Dlamini is more innovative in terms of the range of financial strategies she employs, in contrast to farmers such as Mr Nyawo. However, several important factors beyond her control place her in a situation of greater financial uncertainty. This means that she is less likely to be able to access a microfinance loan in the future. While there are, in addition to its pedagogical role, some clear reasons for making loans conditional upon regular 
saving, such as credit protection and encouraging members to scrutinize management, it is a policy that is bound nonetheless to exclude the most vulnerable members, or its young members such as Sipho. Explaining this in terms of the 'commitment' or 'reliability' of individuals is problematic: in Mrs Dlamini's case, her long period of unpaid work for the bank negates any suggestion that she lacks 'commitment'. A characterization based on individual qualities obscures the structural dimensions, namely the differing access to land and other resources often produced by existing government and private interventions, as in the case of the Makhathini Irrigation Scheme and the more recent closure of the cotton ginnery. ${ }^{12}$

Let us return to the example of Mandla, the member who confronted the SAMAF representative during the meeting. Mandla had been farming for a year when I met him in April 2010. Managing to acquire land by collaborating with several others, he took up farming because he was unable to find any other job. Mandla sold his produce locally at the roadside or by going from house to house. He funded his farming by borrowing from a mashonisa, who charged high rates of interest (R40 a month for every R100 borrowed). As a result he had found it difficult to get any returns from farming yet: indeed, the enterprise - if it was that - was only just surviving financially, and he sometimes had to ask his neighbours for seeds when unable to afford them. He supplemented his income by collecting old iron and other pieces of metal and selling them to the scrapyard, where he was paid for each piece according to its weight.

Mandla joined the microfinance bank because he wanted to receive a loan in order to buy what he called 'professional' (presumably, genetically modified) seeds that would prevent crops from rotting or being eaten by insects. He had become disillusioned with the bank's board members, accusing them of failing to empathize with him. How could he pay R50 a month, he asked, when all of his money had to go to his children or back into farming, or be returned to the mashonisa? The lack of money-generating options available to Mandla enhanced his suspicion of the bank and of those he believed to control it. Indeed, as in the case of both Mrs Dlamini and Sipho, Mandla's inability to invest in the bank will prevent him from accessing its benefits. He and other members began to question whether the bank belonged to them or rather to the SAMAF representative who had spoken to them at the meeting. 'He's only helping the bank, by borrowing money from other banks and people, but he's not helping the people who started it,' Mandla said. This comment suggests that his suspicion also arises from an unclear sense of to whom the bank actually belongs. This is partly to do with the paradoxical role of the government, described above, whereby regulation is tightened while also being implemented indirectly, via 'intermediary' organizations such as the microfinance bank. The resulting elusiveness of government is encapsulated by characters such as the SAMAF representative: he has a functional and moral ambiguity similar to that of 'brokers' elsewhere (James 2011).

Mandla explained why he thought that the bank was nevertheless important despite his complaints, and why he would continue to attend meetings. He told

\footnotetext{
${ }^{12}$ For more information on the history of Makhathini and the impact of changing institutional dynamics there, see Witt et al. 2006.
} 
me that, several years ago, certain farmers in Makhathini had borrowed money from Ithala Bank. But they 'ate' (wasted) all the money they received, and subsequently failed to pay off their debt. This was the reason why farmers from Makhathini now find it difficult to borrow from banks, he explained. Ithala refuses to give a loan to anyone from Makhathini. He continued:

Now that we have our own bank the government will pay the money directly to us. Because it is the government who is paying us, if there is someone who has borrowed from [the bank] and won't pay back, they will put that person in jail. This money is ours to share. If someone fails to pay, they must go to jail. Ithala refuses to give us money because of what those previous people did. Ithala learned their lesson from those people, and don't want the problem repeated. But with the government, that person will pay by going to jail.

Here, Mandla refers to the entrenched history of indebtedness and of loan defaulting in the area, which I outlined above. In describing this, he appropriates a kind of individualizing rhetoric, claiming that irresponsible individuals are to blame for the structural disadvantage now experienced by Makhathini's residents. His comments suggest that, for him, the direct and tangible physical force carried out upon specific individuals by the state is seen as preferable to the generalized exclusion resulting from free-market conditions. ${ }^{13}$ It is also possible that Mandla's comments refer, not to a collection of disparate individuals, but to a category of farmers whom he perceives as better established and more privileged than himself. Indeed, counter-intuitively, it is often only people who already have a certain amount of security that can afford to become indebted (see James, this volume), as was evident in the example of Mr Nyawo.

Mandla's negative attitude about the bank is unrepresentative of its members in general. Most were more hesitant in making any judgements of this kind and, instead, expressed cautious hope and sometimes optimism. Yet it does raise an interesting question about the extent to which expectations concerning the bank's success were related to individual economic vulnerability. Those who did share Mandla's strong suspicions about the credibility of board members were invariably in a situation of financial insecurity so severe that it was impossible for them to invest savings into the bank. Mandla's accusations about its representative, its board members and the loan defaulters are intertwined with his experiences of financial insecurity; an instance of how 'economic reasoning intersects with moral reasoning' in the struggle not only over access to money and resources, but over the 'dominant moralities' that often underpin unequal distribution (Pottier 1999: 24). As in the account of Sipho's failed tender, Mandla's experience shows how encounters with formal institutions and processes are mediated not only by people and events, but also by changing expectations and judgements that often form during periods of delay, and that

\footnotetext{
${ }^{13}$ Mandla's statement is paradoxical given that one of the government's intentions in creating 'financial intermediaries' such as microfinance institutions is precisely to offload responsibility of loan collection. As Porteous and Hazelhurst argue, 'any state is usually ill-equipped to lend directly to its citizens: it lacks the incentives to ensure consistent collection and enforcement of credit contracts' (2004: 189).
} 
may alter trust in the institutional process. In Sipho's case, delay was evidence itself of the breakdown of his role within a process that ultimately excluded him.

In addition to one's own economic circumstances, another significant factor shaping expectations about the bank was that, while members were often proud of having their own 'bank', as Sipho was when he first told me about it, it lacked many of the characteristics associated with commercial banks. Comparisons were continually drawn, and often produced either mockery or unrealistic expectation. One woman told me, for example, that she would only begin to invest in the microfinance bank when it was located in Jozini like the other banks, and when she was issued with a bank card with which to withdraw her money. Thus perceived proximity of the bank to the formal sphere - physically, technologically and aesthetically - was an important aspiration. But because it was unlikely that such proximity would be achieved, its absence was in fact a threat to the stability of the bank.

If it was perceived as lacking legitimacy, this rested on a view of the bank as parochial in relation to the high-street commercial banks. Complaints proliferated about the office being 'in the bush', away from the convenient location of town. When asked whether they would begin to invest the R50 a month that had been agreed upon in the April meeting, many said they would do so when the bank became more established, better functioning, or more conveniently located in town. Others mocked the lack of urbanity and sophistication displayed by the bank. During a private conversation, one member had laughed at the SAMAF representative's suggestion of transferring money from other accounts to the microfinance bank, amused at the thought of how she would cope when travelling to Cape Town in the absence of a branch located in the city. While humorous, comments such as this expressed the real feeling by members that the stability and status of the bank as a feasible institution was under threat. During a meeting on one occasion, Mr Siyaya - the Deputy Mayor of Jozini-encouraged the idea of moving the bank to a location in Jozini, suggesting that the current office was inadequate. He jokingly added that he would not like to put his savings into that office, because the treasurer would 'come along and steal them'. He pointed to the treasurer as he said this, eliciting from him an annoyed chuckle, and from members a stream of laughter. These joking comments nonetheless highlighted the second source of threat to the bank: fears about the possibility of corruption.

This fear was explicit in the earlier comments by Mandla, and also formed an undercurrent of suspicion among members generally. During meetings, board members would address this issue often indirectly, in an attempt to diffuse suspicion, or through humour. During an announcement, the treasurer jokingly lamented the pestering that he received from bank members who, eager to find incriminating evidence against him, interrupted his trips to town by trying to identify the brand status of his new pair of trousers or new bag. This unrelenting badgering of which he claimed to be victim was testimony, his joke implied, to the unreasonable and pedantic nature of corruption accusations.

Other jokes emphasized the perceived dependency of the bank upon the government, by mocking the arbitrariness of the bureaucratic demands placed upon them. The chairperson laughed as he suggested that, prior to shopping, members should put their money into the bank and withdraw it immediately, in order to generate inflow and outflow that was required for the bank to appear in full operation. Again, this light-hearted comment underlined the ambiguous 
proximity of the bank to the state, and its inevitable acquiescence to government bureaucratic demands. Yet it was also a genuine appeal based on the acknowledgement that, should these demands fail to be met, the bank would disintegrate.

Thus, in order to diffuse such fears, those responsible for organizing and managing the bank engaged continually in efforts to gain legitimacy for it, such as calling a meeting in April 2010 to celebrate the formal receipt of the accreditation certificate from SAMAF. In doing this, they were making a claim to official status for the bank. The ritualized receiving of the certificate offered a concrete symbol of successful formalization and acted as a kind of buffer against potential claims to the contrary. Members would frequently comment on the certificate, suggesting that the path was now free of obstacles, as though an end-point had been reached.

Ultimately, then, criticisms centred on the bank's lack of the sophisticated signifiers of 'formality' displayed by commercial banks, as well as on corruption allegations: both indicated the fear held by members of reverting to the messy, uncertain and uncertified realm of the informal. These tensions had to do with efforts at stabilizing the 'domains of cognitive classifications' that are vital for an institution's success (Mary Douglas, quoted in Guyer 2004: 127). They demonstrate how the process of formalization entails the simultaneous production of informal mediums, the two being mutually implicated in each other, rather than the maintenance of two independent spheres (see Hart 2010). Yet the degree of willingness on the part of members to invest money in the bank relied on increasing conformity to a formal façade of the kind exemplified by commercial high-street banks.

\section{CONCLUSION}

When I returned six months later in March 2011, I discovered that the bank had indeed moved to Jozini, where an initial small grant from SAMAF was being used to rent an office. Members were continuing to invest in the bank in greater numbers. Even Sipho admitted that he too would invest in it if he had the money to do so. The bank's progress was marked by delay, however, and many had lost hope altogether. During my three-month visit, no meeting had been held (one was announced and then cancelled). Perhaps as a way of managing this delay, of staving off the disgruntlement caused, board members had reopened the call for membership, and were planning another official opening now that the bank was newly located in town. A concern of which people were increasingly aware was that, should the initiative ever get off the ground, the long membership list might preclude the possibility of most people ever receiving a loan. The bank seemed dangerously close to perpetuating, rather than alleviating, an existing and pervasive mistrust in such initiatives.

On my return I also discovered that Sipho had abandoned his active search for credit, at least for now, and had scaled down his aspirations, having exhausted all avenues. He was using a room in his aunt's house near Jozini to run a store and was selling small items such as soft drinks, cigarettes, apples and sandwiches with the help of other family members. Having spent time reading up on business management in the library, he was keeping strict written records of all transactions. Wedded to a narrative of business acumen, Sipho seemed to 
encapsulate - at least at the aspirational level - the quintessential 'entrepreneur' imaginatively forged in public discourse, an inflated version of the search for 'formality' in which other bank members were engaged. In practice, however, Sipho's scaling down represented something more like conformity with his neighbours. He was making use of networks of kin, their assets and labour, along with reliance on a trickle of pension money, to eke out a living. His efforts at entering formal business had so far been unsuccessful. He, like everyone else, was still waiting for credit.

\section{ACKNOWLEDGEMENTS}

The research and work for this article was funded by a grant from the Economic and Social Research Council of the UK (award RES-062-23-1290), which I gratefully acknowledge. I'd like to thank members of the microfinance bank in Makhathini for their participation, and Thami Nkosi and Zekethelo Cele for their assistance. Thanks to Deborah James, Detlev Krige and David Neves for extensive feedback and to Fraser McNeill for the invitation to present an earlier version of the article in the Anthropology Department at Pretoria University, and to the seminar's participants.

\section{REFERENCES}

Bähre, E. (2007) Money and Violence: financial self-help groups in a South African township. Leiden: Brill.

Bank, L. J. and L. Qambata (1999) 'No visible means of subsistence: rural livelihoods, gender and de-agrarianisation in the Eastern Cape, South Africa', Joint Working Paper, Institute of Social and Economic Research, Rhodes University and African Studies Centre, Leiden.

Bateman, M. (2010) Why Doesn't Microfinance Work? The destructive rise of local neoliberalism. London: Zed Books.

Bryceson, D. F. (2004) 'Agrarian vista or vortex: African rural livelihood policies', Review of African Political Economy 31 (102): 617-29.

Day, C., P. Barron, F. Monticelli and E. Sello (2009) 'District Health Barometer 2007/08', Health Systems Trust, < http://www.hst.org.za/publications/850 >, accessed 22 October 2011.

Francis, E. (2000) Making a Living: changing livelihoods in rural Africa. London: Routledge.

Gupta, A. (1995) 'Blurred boundaries: the discourse of corruption, the culture of politics, and the imagined state', American Ethnologist 22 (2): 375-402.

Guyer, J. I. (2004) Marginal Gains: monetary transactions in Atlantic Africa. Chicago IL: University of Chicago Press.

Hart, K. (2010) 'Informal economy' in K. Hart, J. Laville and A. D. Cattani (eds), The Human Economy: a citizen's guide. Cambridge: Polity Press.

Hull, E. (forthcoming) 'Paperwork and the contradictions of accountability in a South African hospital', Journal of the Royal Anthropological Institute.

James, D. (2007) Gaining Ground? 'Rights' and 'property' in South African land reform. London: Routledge. 
(2011) 'The return of the broker: consensus, hierarchy, and choice in South African land reform', Journal of the Royal Anthropological Institute 17 (2): $318-38$.

Marais, H. (2011) South Africa Pushed to the Limit: the political economy of change. London: Zed Books.

Mayet, M. (2007) 'The new green revolution in Africa: Trojan horse for GMOs?', paper presented at a workshop, 'Can Africa Feed Itself? Poverty, Agriculture and Environment - Challenges for Africa', Oslo, Norway, 6-9 June, < http://zunia.org/uploads/media/knowledge/fixed_20_03_2009_05trojan. pdf $>$, accessed 24 October 2011.

Murray, C. (2000) 'Changing livelihoods: the Free State, 1990s', African Studies 59 (1): $115-42$.

Porteous, D. and E. Hazelhurst (2004) Banking on Change: democratizing finance in South Africa, 1994-2004 and beyond. Cape Town: Double Storey Books.

Pottier, J. (1999) Anthropology of Food: the social dynamics of food security. Cambridge: Polity Press.

Pschorn-Strauss, E. (2005) 'Bt Cotton in South Africa: the case of the Makhathini farmers', Seedling (April): 13-24, < http://www.grain.org/article/entries/492bt-cotton-in-south-africa-the-case-of-the-makhathini-farmers $>$, accessed 24 October 2011.

Servet, J. M. (2010) 'Microcredit' in K. Hart, J. L. Laville and A. D. Cattani (eds), The Human Economy: a citizen's guide. Cambridge: Polity Press.

Shipton, P. (2010) Credit between Cultures: farmers, financiers, and misunderstanding in Africa. New Haven CT and London: Yale University Press.

Sithole, P., A. Todes and A. Williamson (2007) 'Gender and women's participation in municipality-driven development: IDP and project-level participation in Msinga, eThekwini and Hibiscus Coast', Critical Dialogue 3 (1): 31-7.

Thirtle, C., L. Beyers, Y. Ismael and J. Piesse (2003) 'Can GM-technologies help the poor? The impact of Bt Cotton in Makhathini Flats, KwaZulu-Natal', World Development 31 (4): 717-32.

Tsing, A. L. (2000) 'Inside the economy of appearances', Public Culture 12 (1): $115-44$.

Witt, H., R. Patel and M. Schnurr (2006) 'Can the poor help GM crops? Technology, representation and cotton in the Makhathini Flats, South Africa', Review of African Political Economy 33 (109): 497-513.

\section{ABSTRACT}

Drawing on fieldwork in a rural area of KwaZulu-Natal, this article shows how people experience government and other institutions in a patchwork of encounters spread out over time, disjointedly, and via various intermediaries. Aspirations change over time and in response to these encounters. Specifically, the article focuses on the setting up of a government-regulated microfinance institution. I consider the divergence between state-led models of 'entrepreneurship' and the practice of individuals' engagement with the organization and their own expectations about it. One government stipulation was that the bank demonstrated its effective operation through regular inflows and outflows of cash, 
prior to paying out any loans. As such, members were encouraged to invest money in order to qualify for a loan at a later stage. I describe the factors that enhanced or inhibited the willingness of members to invest in the bank, arguing that these strategies were influenced not only by existing levels of economic vulnerability experienced by individuals, but also by particular expectations of the bank, including its perceived reliability, stability and degree of formality vis-à-vis existing conceptions about banking. The example demonstrates that processes of formalization are often partial and incomplete. Rather than examining them in the narrow terms of success or failure, the article focuses on the intersection of moral and economic actions that emerge in the prolonged states of limbo that they create.

\section{RÉSUMÉ}

S'appuyant sur des travaux de recherche menés dans la région rurale du KwaZulu-Natal, cet article montre comment les personnes vivent l'État et d'autres institutions dans une multiplicité de rencontres étalées dans le temps, sans cohérence, et au travers d'intermédiaires divers. Les aspirations évoluent avec le temps et en réaction à ces rencontres. L'article traite en particulier de la création d'une institution de microfinance sous le contrôle de l'État. L'auteur étudie la divergence entre les modèles d'entreprise dirigés par l'État et la pratique des particuliers de nouer le contact avec l'organisation, et les attentes qu'ils en ont. L'État exigeait entre autres que la banque fasse la preuve de son bon fonctionnement à travers des entrées et sorties d'argent régulières, avant d'octroyer des prêts. À ce titre, les adhérents étaient encouragés à investir de l'argent afin de remplir les conditions requises pour l'octroi d'un prêt plus tard. L'auteur décrit les facteurs qui ont renforcé ou diminué la propension des adhérents à investir dans la banque, en soutenant que ces stratégies étaient influencées non seulement par les niveaux de vulnérabilité économique éprouvés alors par les personnes, mais également par les attentes particulières de la banque, y compris sa perception de la fiabilité, de la stabilité et du degré de formalité vis-àvis des conceptions existantes sur l'activité bancaire. Cet exemple démontre que les processus de formalisation sont souvent partiels et incomplets. Plutôt que de les examiner en termes restreints de succès ou d'échec, l'article s'intéresse à l'intersection des actions morales et économiques qui apparaissent dans les états d'incertitude prolongés qu'ils créent. 